\title{
Is Averaging Percentages a Correct Method Statistically?
}

\section{Afraa Talal Barzanji*}

Community Medicine Consultant and CPHQ, Public Health Administration, Madinah, Saudi Arabia

*Corresponding Author: Afraa Talal Barzanji, Community Medicine Consultant and CPHQ, Public Health Administration, Madinah, Saudi Arabia.
Received: December 02, 2021

Published: December 29, 2021

(C) All rights are reserved by Afraa Talal

Barzanji.
There is descriptive and inferential statistic. Mean is a descriptive statistic and it is usually referred to as the average. Mean is a central tendency measure along with mode and median. Not the frequency is summed for mean calculation, but it is the value of each of the observations. For example, in a histogram, if the observations are the scores of students, the frequency would be on $y$ axis, and the scores on $x$ axis. When calculating the mean; the values to be used would be the scores and not the frequency or percentage. Percentage is a descriptive statistic also.

The calculation of mean (average) from percentages can yield non valid result if not done correctly. The right method is to get back the value of each observation that the percentage was calculated from, and then summing them. After that, the result can be divided by the number of the values. On the other hand, summing the percentages and then dividing by the number of the observations is not attributed to the definition/meaning of the mean (arithmetic mean).

For example, we have 10 observations about scores of students:

$80,79,90,92,87,85,83,80,90,88$

The athematic mean is: $80+79+90+92+87+85+83+80+90+88 / 10$

$854 / 10=85.5$

The chart representing above data would be as shown in figure 1.

If the percentages were calculated

$80 / 854 X 100=9.37$

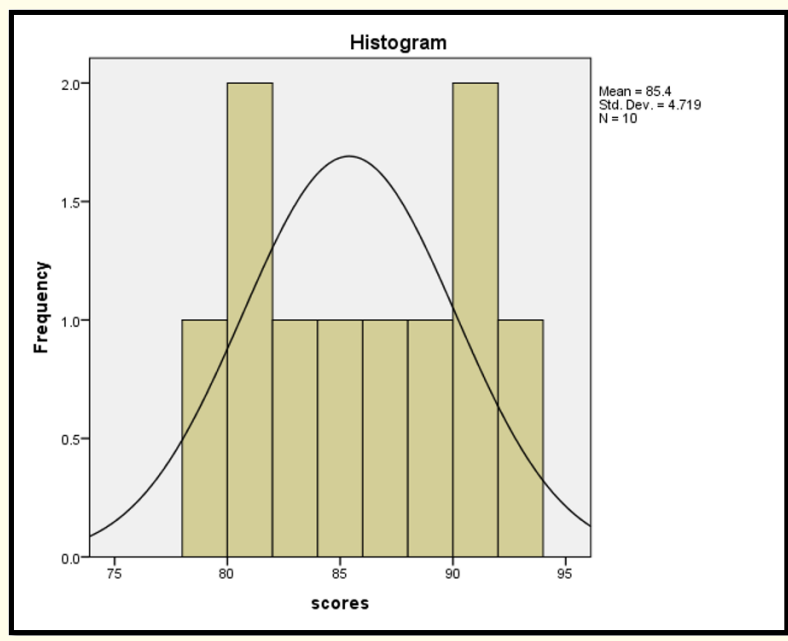

Figure 1: Average of students' scores.
$79 / 854 \times 100=9.25$

$90 / 854 \times 100=10.54$

$92 / 854 \times 100=10.77$

$87 / 854 \times 100=10.19$

$85 / 854 X 100=9.95$

$83 / 854 X 100=9.72$

$80 / 854 \times 100=9.37$

Citation: Afraa Talal Barzanji. "Is Averaging Percentages a Correct Method Statistically?". Acta Scientific Women's Health 4.1 (2022): $22-23$. 
$90 / 854 \times 100=10.54$

$88 / 854 X 100=10.30$.

If the mean was calculated for percentages, considering them as observations:

$9.37 \%+9.25 \%+10.54 \%+10.77 \%+10.19 \%+9.95 \%+9.72 \%+$

$9.37 \%+10.54 \%+10.3 \%$

$=100 / 10$

$=10$

The chart would be as shown in figure 2, (Histogram was used here as a presentation of percentages for the purpose of this example- only).

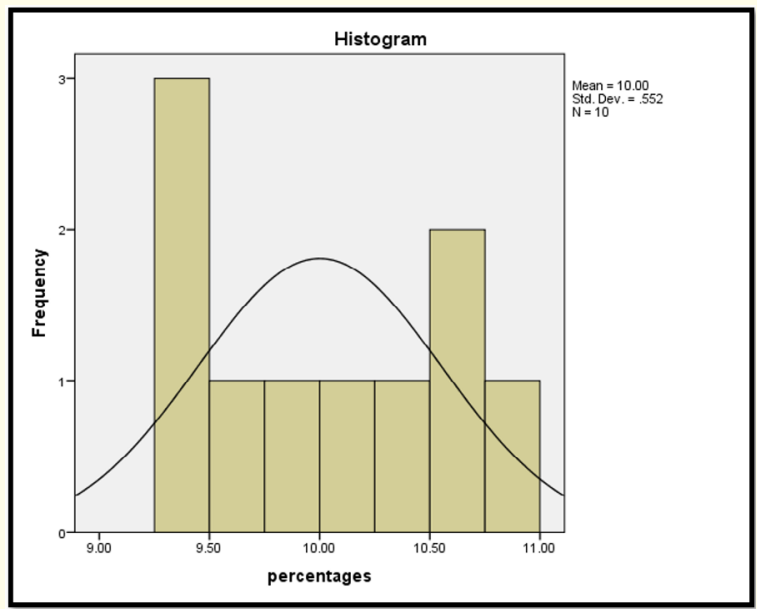

Figure 2: Average percentage of students' scores.

After calculating the mean by using the percentages and not the observations, the result would not be equal to the athematic mean.

What is the right method If the mean is to be calculated from percentages:

The denominator, from which the percentages were determined, must be known (the total of observations) and then from each percentage, the value must be calculated.
Applying to the example:

- $\quad$ The dominator is 854 .

- $\quad$ The data is: $9.37 \%+9.25 \%+10.54 \%+10.77 \%+10.19 \%+$ $9.95 \%+9.72 \%+9.37 \%+10.54 \%+10.3 \%$.

- $\quad$ The right method would be: $(9.37 / 100=0.0937 \times 854=$ $80)+(9.25 / 100=0.025 \times 854=78.99=79)+(10.54 / 100=$ $0.1045 \times 854=90)+(10.77 / 100=0.1077 \times 854=91.97=$ $92)+(10.19 / 100=0.1019 \times 854=87)+(9.95 / 100=0.0995$ X $854=84.97=85)+(9.72 / 100=0.0972 \times 854=83)+$ $(9.37 / 100=0.0937 \times 854=80)+(10.54 / 100=0.1054 X$ $854=90)+(10.3 / 100=0.103 \times 854=87.96=88)=85.5$

In conclusion, the phrase "the average percentage" is not alternative to arithmetic mean.

\section{Bibliography}

- $\quad$ Curtin University Library. "Introduction to statistics: What are descriptive statistics" (last accessed Dec 2021).

- Manikandan S. "Measures of central tendency: The mean". Journal of Pharmacology and Pharmacotherapeutics 2.2 (2011): 140-142

\section{Assets from publication with us}

- Prompt Acknowledgement after receiving the article

- Thorough Double blinded peer review

- Rapid Publication

- Issue of Publication Certificate

- High visibility of your Published work

Website: $\underline{w w w}$.actascientific.com/

Submit Article: www.actascientific.com/submission.php Email us: editor@actascientific.com

Contact us: +919182824667 